\title{
Pain perception and efficacy of local analgesia using $2 \%$ lignocaine, buffered lignocaine, and $4 \%$ articaine in pediatric dental procedures
}

\author{
Afsal M.M, Amit Khatri, Namita Kalra, Rishi Tyagi, Deepak Khandelwal \\ Department of Pedodontics and Preventive Dentistry, UCMS (University of Delhil \& GTB Hospital, Delhi, India
}

\begin{abstract}
Background: The purpose of this study was to compare the pain perception and anesthetic efficacy of $2 \%$ lignocaine with 1:200,000 epinephrine, buffered lignocaine, and 4\% articaine with 1:200,000 epinephrine for the inferior alveolar nerve block.

Methods: This was a double-blind crossover study involving 48 children aged 5-10 years, who received three inferior alveolar nerve block injections in three appointments scheduled one week apart from the next. Pain on injection was assessed using the Wong-Baker Faces pain scale and the sound eye motor scale (SEM). Efficacy of anesthesia was assessed by subjective (tingling or numbness of the lip, tongue, and corner of mouth) and objective signs (pain on probing).

Results: Pain perception on injection assessed with Wong-Baker scale was significantly different between buffered lignocaine and lignocaine $(\mathrm{P}<0.001)$ and between buffered lignocaine and articaine $(\mathrm{P}=0.041)$. The onset of anesthesia was lowest for buffered lignocaine, with a statistically significant difference between buffered lignocaine and lignocaine $(\mathrm{P}<0.001)$. Moreover, the efficacy of local analgesia assessed using objective signs was significantly different between buffered lignocaine and lignocaine $(\mathrm{P}<0.001)$ and between lignocaine and articaine.

Conclusion: Buffered lignocaine was the least painful and the most efficacious anesthetic agent during the inferior alveolar nerve block injection in 5-10-year-old patients.
\end{abstract}

Keywords: Articaine; Buffers; Lignocaine; Pain Scale.

This is an Open Access article distributed under the terms of the Creative Commons Attribution Non-Commercial License (http://creativecommons.org/licenses/by-nc/4.0/) which permits unrestricted non-commercial use, distribution, and reproduction in any medium, provided the original work is properly cited.

\section{INTRODUCTION}

Pain is an unpleasant sensory and emotional experience associated with actual or potential tissue damage [1]. Pain is an inevitable factor during various dental procedures and it is one of the major reasons why a patient may fear dental treatments, which is especially true for pediatric dental patients. Therefore, the effective control of pain during dental procedures is an important prerequisite of pediatric dentistry. In dentistry, the employment of local anesthesia as a means of pain control has been one of the medical marvels of the twentieth century. Lignocaine hydrochloride has been the most commonly used anesthetic agent since its clinical availability in 1941. Hence, it is considered as the "gold standard" to which all new local anesthetics are compared [2]. Buffering the lignocaine solution to a neutral $\mathrm{pH}$ as a method of analgesia has been recommended [3]. According to Malamed et al., increasing the $\mathrm{pH}$ of lignocaine $\mathrm{HCl}$ immediately before administration significantly increases the amount of the active anesthetic form available; additionally, this process results in several clinical advantages including greater patient comfort,

Received: March 13, 2019 • Revised: April 4, 2019 • Accepted: April 10, 2019

Corresponding Author: Amit Khatri, Department of Pedodontics and Preventive Dentistry, UCMS (University of Delhi) \& GTB Hospital, DELHI-95

E-mail: Khatri9804@rediffmail.com

Copyright(C) 2019 Journal of Dental Anesthesia and Pain Medicine 
more rapid onset of anesthesia, and decreased post injection tissue injury [2].

In 1976, a new amide local anesthetic, articaine HCl was introduced. The clinical effects of articaine are similar to lidocaine; however, it also has additional properties that make the drug quite attractive in dentistry. Articaine is unique among local anesthetics because it is the only local anesthetic which possesses a thiophene group instead of a benzene ring; it is also the only widely used local anesthetic that contains an ester group. These properties account for the better performance of articaine over other local anesthetics [4]; however, it is ironical that the administration of local anesthetic itself may be a source of pain and anxiety to some patients [5,6], which might result in patients avoiding dental care and follow-up $[7,8]$.

It has been suggested that the application of topical anesthetic agents prior to puncture $[5,9,10]$, warming up the local anesthetic [11,12], and buffering [2] of the anesthetic agents may reduce the pain caused by the administration of local anesthesia. The literature search shows that limited clinical research has been done to test the pain perception and anesthetic efficacy of lignocaine, buffered lignocaine, and articaine in pediatric patients. Hence this study was conducted to compare the pain perception and anesthetic efficacies of $2 \%$ lignocaine containing 1:200,000 epinephrine, buffered lignocaine, and 4\% articaine containing 1:200,000 epinephrine among pediatric patients requiring the inferior alveolar nerve block during vital pulp therapy or extraction.

\section{MATERIALS AND METHODS}

This prospective, randomized, double-blind, crossover study was conducted in the Department of Pedodontics and Preventive Dentistry, University College of Medical Science (UCMS) and Guru Teg Bahadur Hospital (GTBH), Delhi, India after due approval from the Institutional review board (IRB) of UCMS and GTBH, Delhi. (IRB Number: ECR-1129/Inst/DL/2018)

Samples of 48 healthy children were recruited for the study (Table 1). The inclusion criteria were patients between 5 and 10 years of age who: 1) had not undergone any prior dental treatment; 2) had a minimum of three teeth requiring treatment (such as vital pulp therapy or extraction) under local anesthesia and, 3) exhibited Frankl's behavior rating grade three or four. The exclusion criteria were patients who: 1) were allergic to local anesthesia; 2) had a history of a medicallycompromised condition or, 3) had already undergone dental treatment for any other tooth. In total, we performed 82 extractions and 53 pulp therapies during the three visits of the 48 patients who were included in this study.

Subjects were randomly allocated via $3 / 3$ balanced Latin square design; 6 patients were recruited in two blocks and assigned their treatments. Since there was an odd number of the visit in the study, orthogonal Latin square was used in which each column represented the order of anesthetic agents (A, B, C) given to each subject to achieve a balance [13].

Thus, we required the sample size to be a multiple of 6 which informed our decision to enroll 48 subjects for this study. Each patient was randomly assigned to receive either 2\% lignocaine with 1:200,000 epinephrine (Kwality Pharmaceuticals Ltd., Amritsar-India), buffered lignocaine, or 4\% articaine with 1:200,000 epinephrine (Septanest N., Septodont, France) for the first visit; the other two local anesthetic solutions were administered in the second and third visit randomly. Buffered lignocaine was freshly prepared by mixing sodium bicarbonate with

\begin{tabular}{|c|c|c|c|}
\hline \multirow{2}{*}{ Period (visit) } & \multicolumn{3}{|c|}{ Subject } \\
\cline { 2 - 4 } & 1 & 2 & 3 \\
\hline 1 & $\mathrm{~A}$ & $\mathrm{~B}$ & $\mathrm{C}$ \\
\hline 2 & $\mathrm{~B}$ & $\mathrm{C}$ & $\mathrm{A}$ \\
\hline 3 & $\mathrm{C}$ & $\mathrm{A}$ & $\mathrm{B}$ \\
\hline
\end{tabular}

\begin{tabular}{|c|c|c|}
\hline \multicolumn{3}{|c|}{ Subject } \\
\hline 4 & 5 & 6 \\
\hline A & B & C \\
\hline C & A & B \\
\hline B & C & A \\
\hline
\end{tabular}


Table 1. Profile of the study population

\begin{tabular}{|c|c|c|}
\hline & Years & Number of Patients (\%) \\
\hline \multirow{6}{*}{ Age } & 5 & $5(10.4)$ \\
\hline & 6 & $10(20.8)$ \\
\hline & 7 & $6(12.5)$ \\
\hline & 8 & $9(18.8)$ \\
\hline & 9 & $12(25)$ \\
\hline & 10 & $6(12.5)$ \\
\hline \multirow{2}{*}{ Gender } & Male & $29(60.4)$ \\
\hline & Female & $19(39.6)$ \\
\hline \multirow{2}{*}{ Mean height $(\mathrm{cm})$} & Male & $128.3 \pm 34.65$ \\
\hline & Female & $127.9 \pm 23.9$ \\
\hline \multirow{2}{*}{ Mean weight $(\mathrm{kg})$} & Male & $26.7 \pm 6.34$ \\
\hline & Female & $25.4 \pm 5.54$ \\
\hline
\end{tabular}

Table 2. Sound eye motor (SEM) scoring criteria

\begin{tabular}{|c|c|c|c|c|}
\hline \multirow{2}{*}{$\begin{array}{l}\text { Observations of } \\
\text { possible indications } \\
\text { of pain }\end{array}$} & \multicolumn{4}{|c|}{ Comfort or Pain level } \\
\hline & 1-Comfort & 2-Mild discomfort & 3-Moderate painful & 4-Painful \\
\hline Sound & No sound indicating pain & $\begin{array}{l}\text { Nonspecific sounds; possible } \\
\text { indication of pain }\end{array}$ & $\begin{array}{l}\text { Specific verbal complaints (such as } \\
\text { "OW"), raises voice }\end{array}$ & $\begin{array}{l}\text { Verbal complaint indicates } \\
\text { intense pain (such as } \\
\text { screaming, sobbing) }\end{array}$ \\
\hline Eye & $\begin{array}{l}\text { No eye signs of } \\
\text { discomfort }\end{array}$ & $\begin{array}{l}\text { Eyes open wide, show of } \\
\text { concern, no tears }\end{array}$ & Watery eyes, eyes flinching & $\begin{array}{l}\text { Crying, tears running down the } \\
\text { face }\end{array}$ \\
\hline Motor & $\begin{array}{l}\text { Hands relaxed no } \\
\text { apparent body tension }\end{array}$ & $\begin{array}{l}\text { Hands showing some distress } \\
\text { or tension; grasping of the chair } \\
\text { owing to discomfort, muscular } \\
\text { tension }\end{array}$ & $\begin{array}{l}\text { Random movement of the arms or } \\
\text { body without any aggressive } \\
\text { intention of physical contact, } \\
\text { grimacing or twitching }\end{array}$ & $\begin{array}{l}\text { Movement of the hands to } \\
\text { make aggressive physical } \\
\text { contact (such as pushing, } \\
\text { pulling head away) }\end{array}$ \\
\hline
\end{tabular}

lignocaine solution in a 1:10 ratio by volume. A $30 \mathrm{ml}$ vial of commercially available $2 \%$ lignocaine hydrochloride with 1:200,000 epinephrine and $3 \mathrm{ml}$ of $8.4 \%$ bicarbonate (Neon Laboratories Ltd.) were mixed into the vial to make the final preparation [3]. The $\mathrm{pH}$ of the commercially available solution was found to be 4.33 , while the $\mathrm{pH}$ of the buffered solution was 7.32. Either solution, at a volume of $1.8 \mathrm{ml}$, was dispensed in a disposable $2 \mathrm{ml}$ syringe with a 27 -gauge needle, which was used for all inferior alveolar nerve block injections.

Pain perception during the administration of local anesthesia was assessed by the SEM scale [14], and the Wong-Baker Faces pain rating scale [15] as the primary outcome; the time of onset and efficacy of analgesia was determined as the secondary outcome.

\section{Criteria for assessment}

\subsection{Pain perception}

On the day of the appointment, every patient was reassessed for inclusion and exclusion criteria. After seating the patient on the dental chair, topical anesthetic agent (Procaine-B 20\% Benzocaine) was applied over the injection site one minute before the injection. The first researcher then administered the local anesthetic solution using the standardized inferior alveolar nerve block (IANB) technique. The first researcher was handed the loaded syringe ( $2 \mathrm{ml}$ disposable syringe with 27 -gauge needle) by the second researcher and was unaware of the type of local anesthesia that he was administering. The trained assistant who was pre-calibrated and blinded to the type of solution recorded the SEM scale (Table 2) during anesthetic deposition from a distance of 1.5 meters.

Using a standardized Wong-Baker Faces pain scale (FPS), pain perception was also judged subjectively by the patient who was also blind to the type of anesthetic agent (Fig. 1). The child was asked to point at the face as per his experience. Subsequently, the number corresponding to the face selection was recorded. 


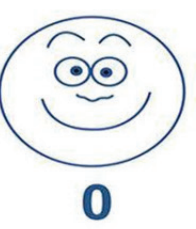

No

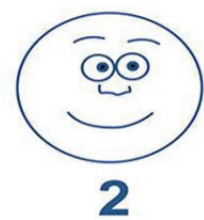

Hurts

Little Bit

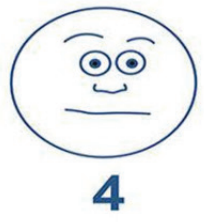

Hurts

Little More

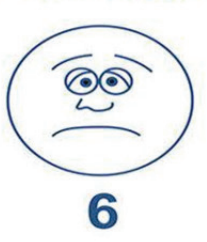

Hurts

Even More

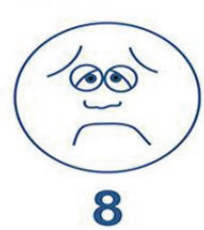

Hurts

Whole Lot

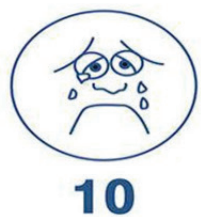

Hurts

Worst

Fig. 1. Wong-Baker FACES ${ }^{\circledR}$ Pain Rating Scale

Table 3. Wong-Baker scale score and SEM score

\begin{tabular}{|c|c|c|c|c|}
\hline & $\begin{array}{c}\text { Lignocaine } \\
(\text { mean } \pm \text { SD) }\end{array}$ & $\begin{array}{c}\text { Buffered } \\
\text { Lignocaine } \\
\text { (mean } \pm \text { SD) }\end{array}$ & $\begin{array}{c}\text { Articaine } \\
(\text { mean } \pm \text { SD) }\end{array}$ & P-value \\
\hline $\begin{array}{l}\text { Wong Baker } \\
\text { Scale }\end{array}$ & $3.2 \pm 1.059$ & $2.54 \pm 1.352$ & $3.00 \pm 1.095$ & $\begin{array}{l}L \text { vs } B L- \\
P<0.001 \\
B L \text { vs } A-0.047 \\
L \text { vs } A-0.371\end{array}$ \\
\hline SEM & $2.0 \pm 0.075$ & $1.97 \pm 0.157$ & $2.12 \pm 0.040$ & $\begin{array}{l}L \text { vs } B L-0.686 \\
B L \text { vs } A-1.00 \\
L \text { vs } A-1.00\end{array}$ \\
\hline
\end{tabular}

${ }^{*} \mathrm{P}<0.05$ is significant

\subsection{The onset of Anesthesia}

The onset of anesthesia was measured in seconds by an objective sign (gingival probing). Probing was carried out with a blunt-ended Williams's periodontal probe by gently probing on the gingival, which was initiated 30 seconds after injection and checked every 15 seconds using a stopwatch until the child patient experienced the absence of pain.

\subsection{Efficacy of anesthesia}

Efficacy of anesthesia was assessed both objectively and subjectively. The subjective sign was assessed by repeatedly asking the child about numbness on the tongue, corner of the mouth, and lip every 30 seconds; this was repeated until the child experienced complete numbness. The objective sign was assessed by gingival probing as explained above for the onset of anesthesia; this was repeated until the child experienced the complete absence of pain.

The data were recorded and subjected to statistical analysis using the statistical package for the social sciences (SPSS) 20.0 software. Three factors analysis of variance (ANOVA) which was adjusted for subject block and visit (period) was used for analyzing the differences.

\section{RESULTS}

Table 3 shows the Wong-Baker scale and the SEM scale scores for pain perception during anesthetic injection. When tested using three-factor ANOVA, the difference in the Wong-Baker scale score was found to be statistically significant between buffered lignocaine and lignocaine $(\mathrm{P}<0.001)$, and buffered lignocaine and articaine $(\mathrm{P}=0.041)$. However, using the SEM scale, even though there was a difference in the scores obtained for all the three agents (least score for buffered lignocaine), this difference was not statistically significant. The motor component value was significantly different between the buffered lignocaine and articaine $(\mathrm{P}=0.018)$.

Table 4 shows the time of onset of anesthesia (measured in seconds) for all the three local anesthetic agents. Mean $( \pm$ SD) time of onset was $73.63( \pm 13.45)$ 
Table 4. Time elapsed before the onset of action and attaining maximum efficacy (using the objective signs)

\begin{tabular}{|c|c|c|c|c|}
\hline & $\begin{array}{c}\text { Lignocaine } \\
(\text { mean } \pm \text { SD) }\end{array}$ & $\begin{array}{c}\text { Buffered } \\
\text { Lignocaine } \\
\text { (mean } \pm \text { SD) }\end{array}$ & $\begin{array}{c}\text { Articaine } \\
\text { (mean } \pm \text { SD) }\end{array}$ & P-value \\
\hline $\begin{array}{l}\text { Onset of action } \\
\text { (seconds) }\end{array}$ & $73.63 \pm 13.458$ & $60.00 \pm 10.377$ & $68.38 \pm 16.555$ & $\begin{array}{l}L \text { vs. } B L<0.001 \\
B L \text { vs. } A-0.026 \\
L \text { vs. } A-0.157\end{array}$ \\
\hline $\begin{array}{l}\text { Time taken for } \\
\text { maximum } \\
\text { efficacy (objective sign) }\end{array}$ & $85.63 \pm 12.37$ & $75.00 \pm 15.45$ & $79.38 \pm 18.55$ & $\begin{array}{l}L \text { vs. } B L-0.001 \\
B L \text { vs. } A-0.157 \\
L \text { vs. } A-0.017\end{array}$ \\
\hline
\end{tabular}

${ }^{*} P<0.05$ is significant

Table 5. Time taken before maximum efficacy (subjective sign)

\begin{tabular}{|c|c|c|c|c|c|c|c|}
\hline & \multicolumn{2}{|c|}{ Lignocaine } & \multicolumn{2}{|c|}{ Buffered lignocaine } & \multicolumn{2}{|c|}{ Articaine } & \multirow{2}{*}{ P-value } \\
\hline & Mean & SD & Mean & SD & Mean & SD & \\
\hline $\begin{array}{l}\text { Numbness } \\
\text { on lip }\end{array}$ & 86.4 & 15.50 & 77.4 & 12.45 & 84.0 & 0.494 & $\begin{array}{l}L \text { vs } B L-0.016 \\
B L \text { vs } A-0.025 \\
L \text { vs } A-01.00\end{array}$ \\
\hline $\begin{array}{l}\text { Numbness } \\
\text { on corner } \\
\text { of mouth }\end{array}$ & 85.2 & 14.49 & 78.6 & 13.46 & 82.8 & 0.489 & $\begin{array}{l}L \text { vs } B L-0.030 \\
B L \text { vs } A-0.042 \\
L \text { vs } A-0.148\end{array}$ \\
\hline $\begin{array}{l}\text { Numbness } \\
\text { on tongue }\end{array}$ & 86.4 & 15.50 & 78.6 & 13.47 & 90.0 & 0.505 & $\begin{array}{l}L \text { vs } B L-0.016 \\
B L \text { vs } A-0.001 \\
L \text { vs } A-0.156\end{array}$ \\
\hline
\end{tabular}

${ }^{*} P<0.05$ is significant

Table 6. Wong-Baker scale score (age-wise) for pain perception with lignocaine, buffered lignocaine, and articaine

\begin{tabular}{|c|c|c|c|c|c|c|}
\hline \multirow{3}{*}{ Age (in years) } & \multicolumn{6}{|c|}{ Wong-Baker scale score \pm standard deviation } \\
\hline & \multicolumn{2}{|c|}{ Lignocaine } & \multicolumn{2}{|c|}{ Buffered lignocaine } & \multicolumn{2}{|c|}{ Articaine } \\
\hline & Mean & SD & Mean & SD & Mean & SD \\
\hline 6 & 3.8 & 0.63 & 3.4 & 0.96 & 3.4 & 0.96 \\
\hline 7 & 3 & 1.67 & 3 & 1.67 & 3 & 1.67 \\
\hline 8 & 3.3 & 1.0 & 2.66 & 1.0 & 2.66 & 1.0 \\
\hline 9 & 3.16 & 1.02 & 2.16 & 1.58 & 2.16 & 1.58 \\
\hline 10 & 3 & 1.09 & 1.33 & 1.03 & 1.33 & 1.03 \\
\hline
\end{tabular}

seconds, $60.00( \pm 10.37)$ seconds, and $68.38( \pm 16.555)$ seconds for lignocaine, buffered lignocaine, and articaine, respectively. Furthermore, the differences in the time of onset were statistically significant between buffered lignocaine and lignocaine $(\mathrm{P}<0.001)$ and buffered lignocaine and articaine $(\mathrm{P}=0.026)$. The mean time $( \pm$ SD) taken for achieving maximum efficacy (using objective signs) was $75.00( \pm 15.45)$ seconds, 85.63 ( \pm 12.37) seconds, and 79.38 ( \pm 18.55) seconds for lignocaine, buffered lignocaine, and articaine, respectively. The difference was statistically significant between buffered lignocaine and lignocaine $(\mathrm{P}<0.001)$ and buffered lignocaine and articaine $(\mathrm{P}=0.026)$.

Table 5 shows the time before maximum efficacy (subjective sign) was attained. The difference between the time taken to attain complete numbness in the lip, corner of the mouth, and tongue was found to be statistically significant between buffered lignocaine and lignocaine and buffered lignocaine and articaine.

Table 6 shows the age-wise assessment of the Wong-Baker scale scores; the scores were lowest among the 10-year-olds and highest among the 6-year-olds. Furthermore, among all three agents and age groups, buffered lignocaine was found to be the least painful 
Table 7. Sound eye motor (SEM) scale score (age-wise) with pain perception for lignocaine, buffered lignocaine, and articaine

\begin{tabular}{|c|c|c|c|c|c|c|c|c|c|}
\hline \multirow{2}{*}{$\begin{array}{l}\text { Age } \\
\text { (in } \\
\text { years) }\end{array}$} & \multicolumn{3}{|c|}{ Sound component } & \multicolumn{3}{|c|}{ Eye component } & \multicolumn{3}{|c|}{ Motor component } \\
\hline & Lignocaine & $\begin{array}{c}\text { Buffered } \\
\text { lignocaine }\end{array}$ & Articaine & Lignocaine & $\begin{array}{c}\text { Buffered } \\
\text { lignocaine }\end{array}$ & Articaine & Lignocaine & $\begin{array}{c}\text { Buffered } \\
\text { lignocaine }\end{array}$ & Articaine \\
\hline 5 & $2.4 \pm 1.30$ & $2.4 \pm 1.14$ & $2.6 \pm 1.34$ & $2.2 \pm 0.83$ & $2.8 \pm 0.83$ & $2.6 \pm 0.83$ & $2.3 \pm 1.34$ & $2.2 \pm 1.30$ & $2.6 \pm 1.34$ \\
\hline 6 & $2.3 \pm 0.82$ & $1.9 \pm 0.73$ & $2.1 \pm 0.99$ & $2.2 \pm 0.60$ & $2.0 \pm 0.66$ & $2.1 \pm 0.5$ & $2.3 \pm 0.60$ & $1.5 \pm 0.52$ & $2.1 \pm 0.99$ \\
\hline 7 & $1.5 \pm 0.54$ & $0.8 \pm 0.51$ & $1.5 \pm 0.54$ & $1.5 \pm 0.54$ & $1.5 \pm 0.54$ & $1.66 \pm 0.86$ & $1.5 \pm 0.67$ & $1.5 \pm 0.54$ & $1.5 \pm 0.54$ \\
\hline 8 & $2.5 \pm 1.01$ & $2.00 \pm 1.11$ & $2.77 \pm 1.09$ & $2.5 \pm 1.01$ & $2.22 \pm 0.97$ & $2.66 \pm 0.86$ & $2.22 \pm 0.66$ & $2.0 \pm 0.70$ & $2.77 \pm 1.09$ \\
\hline 9 & $.16 \pm 0.71$ & $2.0 \pm 0.79$ & $2.25 \pm 0.62$ & $2.16 \pm 0.80$ & $2.25 \pm 1.05$ & $2.08 \pm 0.79$ & $1.91 \pm 0.66$ & $1.08 \pm 0.90$ & $2.25 \pm 0.62$ \\
\hline 10 & $1.16 \pm 0.40$ & $1.0 \pm 0.00$ & $1.33 \pm 0.51$ & $2.0 \pm 0.89$ & $1.6 \pm 0.51$ & $1.66 \pm 0.86$ & $1.5 \pm 0.54$ & $1.5 \pm 0.54$ & $1.33 \pm 0.51$ \\
\hline
\end{tabular}

agent during administration.

Table 7 shows the age-wise assessment of the SEM scale scores; the scores were highest among 5-year-olds and lowest among the 10-year-olds. Additionally, the lowest score was observed for buffered lignocaine in all age groups, except among 9-year-olds.

\section{DISCUSSION}

Pain control is an important aspect in the administration of local anesthesia in pediatric dental practice; thus, several procedural, behavioral, and pharmacological strategies have been proposed to alleviate pain and discomfort during pediatric dental treatment. Hence, buffering the local anesthetic solution has been suggested as a means of reducing the pain caused by the administration of the local anesthetic. This pain, which usually manifests as a burning sensation can be quite severe, and has been attributed to the increased hydrogen ions in the local tissue environment caused by the acidity of lignocaine. Consequently, the addition of sodium bicarbonate to the local anesthetic preparation raises the $\mathrm{pH}$ of the formulation thereby reducing the pain during anesthetic administration [3].

Articaine is fundamentally different from lignocaine and the other amide anesthetics, due to its possession of a thiophene ring instead of the benzene ring that is typically present in these group of compounds. It has been speculated in the scientific literature that the thiophene ring encourages rapid transport across the nerve cell membrane, which may account for the reported faster onset of action and the decreased pain during administration [16]. This double-blind prospective cross-over study was conducted to assess the pain perception and efficacy of lignocaine, buffered lignocaine, and articaine.

As the inferior alveolar nerve block has claimed as one of the most painful and stressful procedures of pediatric dentistry [17], the present study employed this procedure to compare the pain perception and efficacy of local analgesia. However, because pain is extremely difficult to quantify in children, two different scales were used for pain assessment. The Wong-Baker Faces pain scale was used for subjective measurement; it showed good construct validity as a self-report pain measurement [15]. Conversely, the SEM [14] was used is an objective scale that measures pain or discomfort taking into account the SEM components of the child's response to stimulation.

In the present study, pain perception recorded with the help of the self-reported score (Wong-Baker scale) were different for all three formulations, and the patients showed a preference for buffered lignocaine; however, articaine was better tolerated by children than lignocaine. The difference between the pairings of lignocaine and buffered lignocaine, and buffered lignocaine and articaine were statistically significant. However, the SEM scale score recorded for pain perception between lignocaine and buffered lignocaine, and buffered lignocaine and articaine was not statistically significant.

The result of this study showed that Wong-Baker and SEM scores were lower for buffered lignocaine than articaine and lignocaine; this could be attributed to the decreased tissue irritation from the more physiologic $\mathrm{pH}$ of the buffered solution. Alternatively, because buffering 
increases the concentration of uncharged lignocaine particles, the faster onset of nerve blockade may help explain the decreased sensation of pain [18]. Malamed et al. [19] and Kashyap et al. [20] both reported more comfortable injections with alkalinized $2 \%$ lignocaine when used for the inferior alveolar nerve block; whereas a study by Chopra $\mathrm{R}$ et al. reported that there was no difference in the pain perception between lignocaine and buffered lignocaine [3].

Pain score obtained from both scales for articaine was lesser compared to lignocaine, even though the difference was not significant. Similar results were seen in a study conducted by Steele EA et al. [16] where the comparison was made between the pain induced by lignocaine and articaine during infiltration in eyelid surgery. Additionally, Sumer $\mathrm{M}$ et al. compared injection pain between articaine (with adrenaline), prilocaine (with phenylpressin), and lidocaine (with adrenaline) and discovered that the pain on injection for all three anesthetic agents was similar [21].

Age-wise assessment of Wong-Baker scale score for pain perception was lowest among 10-year-olds. Additionally, buffered lignocaine had the lowest WongBaker scale score for all the age groups, which could suggest that buffered lignocaine is the least painful anesthetic agent amongst all three agents. Furthermore, age-wise assessment of the SEM scale was highest among the 5-year-olds and lowest among the ten-year-old age group. Hence, this suggests that as the age of the child increases, the pain perception while injecting the local anesthetic decreases; this could be attributed to an increased pain tolerance with age.

In the current study, the time to onset after the administration of local anesthetic agent was found to be statistically significant between 1) lignocaine and buffered lignocaine and 2) buffered lignocaine and articaine. Similar findings were reported by Malamed et al. [19] for the IANB, and by Kashyap et al. [20] for the inferior alveolar, lingual, and long buccal nerve blocks; however, Chopra $\mathrm{R}$ et al. reported a similar onset of anesthesia for both lignocaine and buffered lignocaine.[3] Similarly, a faster onset with buffering could not be demonstrated by Whitcomb et al.[22] and Hobeich et al.[23] for the inferior alveolar nerve block and maxillary infiltrations, respectively. Chow et al. also discovered that alkalinizing a local anesthetic did not quicken the onset of a regional upper limb nerve blockade [24].

In the present study, the efficacy of different local anesthetics such as lignocaine, buffered lignocaine, and articaine was assessed with the help of subjective signs (numbness on the lip, tongue, and corner of mouth) and objective signs (pain while probing). The results of this study suggest that buffered lignocaine is a more efficacious local anesthetic, whereas lignocaine and articaine are equally effective in children. This was in agreement with Malamed et al. [19] who reported that articaine is as effective as lignocaine. Conversely, the study conducted by Saraf SP et al. [25] compared the anesthetic efficacy of $4 \%$ articaine and $2 \%$ lignocaine for the anterior superior alveolar nerve block and infraorbital nerve block and reported that $4 \%$ articaine was more efficacious than $2 \%$ lignocaine. Kambalimath $\mathrm{DH}$ et al., also reported in their study that there was no statistically significant difference in the onset of action and duration of anesthesia between articaine and lignocaine solutions [26].

In conclusion, pain perception varies with lignocaine, buffered lignocaine, and articaine administration. Among these agents, buffered lignocaine was found to be least painful agent during injection in patients aged 5-10 years old. The local anesthetic efficacy of lignocaine, buffered lignocaine, and articaine showed a statistically significant difference between them. Buffered lignocaine was revealed as the most efficacious anesthetic agent; however, articaine and lignocaine were also found to be equally effective.

\section{AUTHOR ORGIDS}

Afsal M.M: https://orcid.org/0000-0001-9231-7096

Amit Khatri: https://orcid.org/0000-0001-8071-0501

Namita Kalra: https://orcid.org/0000-0001-6216-827X

Rishil Tyagi: https://orcid.org/0000-0003-4467-961X

Deepak Khandelwal: https://orcid.org/0000-0001-8879-9088 
CONFLICT OF INTEREST: None of the authors have any conflicts of interest to declare.

\section{REFERENCES}

1. Gorczyca R, Filip R, Walczak E. Psychological aspects of pain. Ann Agric Environ Med 2013; 20: 23-7.

2. Malamed SF. Handbook of local anesthesia. 6th ed. St. Louis, Mo., USA: Mosby. 2012 58-63.

3. Chopra R, Jindal G, Sachdev V, Sandhu M. Double-blind crossover study to compare pain experience during inferior alveolar nerve block administration using buffered two percent lidocaine in children. Pediatr Dent 2016; 38: 25-9.

4. Ferger P, Marxkors R. A new anesthetic in dental prosthetics. Dtsch Zahnarztl Z 1973; 28: 87-9.

5. Al-Samadani KH, Gazal G. Effectiveness of benzocaine in reducing deep cavity restoration and post-extraction stress in dental patients. Saudi Med J 2015; 36: 1342-7.

6. Davoudi A, Rismanchian M, Akhavan A, Nosouhian S, Bajoghli F, Haghighat A, et al. A brief review on the efficacy of different possible and nonpharmacological techniques in eliminating discomfort of local anesthesia injection during dental procedures. Anesth Essays Res 2016; 10: 13-6.

7. Gordon D, Heimberg RG, Tellez M, Ismail AI. A critical review of approaches to the treatment of dental anxiety in adults. J Anxiety Disord 2013; 27: 365-78.

8. Yuen HK, Wolf BJ, Bandyopadhyay D, Magruder KM, Selassie AW, Salinas CF. Factors that limit access to dental care for adults with spinal cord injury. Spec Care Dentist 2010; 30: 151-6.

9. Al-Melh MA, Andersson L. Comparison of topical anesthetics (EMLA/Oraqix vs. benzocaine) on pain experienced during palatal needle injection. Oral Surg Oral Med Oral Pathol Oral Radiol Endod 2007; 103: e16-20.

10. Al-Melh MA, Andersson L. Reducing pain from palatal needle stick by topical anesthetics: a comparative study between two lidocaine/prilocaine substances. J Clin Dent 2008; 19: 43-7.
11. Hogan ME, vanderVaart S, Perampaladas K, Machado M, Einarson TR, Taddio A. Systematic review and metaanalysis of the effect of warming local anesthetics on injection pain. Ann Emerg Med 2011; 58: 86-98.e1.

12. Leaper D. Warming local anaesthetic prior to injection reduces injection pain. Evid Based Med 2012; 17: 46-7.

13. Conway CM, Ellis DB, King NW. A comparison of the acute hemodynamic effects of thiopentone, methohexitone and propanidid in the dog. Br J Anaesth 1968; 40: 736-45.

14. Wright GZ, Weinberger SJ, Marti R, Plotzke O. The effectiveness of infiltration anesthesia in the mandibular primary molar region. Pediatr Dent 1991; 13: 278-83.

15. Wong DL, Baker CM. Pain in children: comparison of assessment scales. Pediatr Nurs 1988; 14: 9-17.

16. Steele EA, Ng JD, Poissant TM, Campbell NM. Comparison of injection pain of articaine and lidocaine in eyelid surgery. Ophthalmic Plast Reconstr Surg 2009; 25: $13-5$.

17. Costa RSM, Ribeiro SN, Cabral ED. Determinants of painful experience during dental treatment. Rev Dor. São Paulo 2012; 13: 365-70.

18. Shehab LA, Basheer B, Baroudi K. Effectiveness of lidocaine Denti patch $^{\circledR}$ system versus lidocaine gel as topical anesthetic agent in children. J Indian Soc Pedod Prev Dent 2015; 33: 285-90.

19. Malamed SF, Gagnon S, Leblanc D. A comparison between articaine $\mathrm{HCl}$ and lidocaine $\mathrm{HCl}$ in pediatric dental patients. Pediatr Dent 2000; 22: 307-11.

20. Kashyap VM, Desai R, Reddy PB, Menon S. Effect of alkalinisation of lignocaine for intraoral nerve block on pain during injection and speed of onset of anesthesia. Br J Oral Maxillofac Surg 2011; 49: e72-75.

21. Sumer M, Misir F, Celebi N, Mugalai M. A comparison of injection pain with articaine with adrenaline, prilocaine with phenylpressin and lidocaine with adrenaline. Med Oral Patol Oral Cir Bucal 2008; 13: E427-30.

22. Whitcomb M, Drum M, Reader A, Nusstein J, Beck M. A prospective, randomized, double-blind study of the anesthetic efficacy of sodium bicarbonate buffered $2 \%$ lidocaine with 1:100,000 epinephrine in inferior alveolar nerve blocks. Anesth Prog 2010; 57: 59-66. 
23. Hobeich P, Simon S, Schneiderman E, He J. A prospective, randomized, double-blind comparison of the injection pain and anesthetic onset of $2 \%$ lidocaine with 1:100,000 epinephrine buffered with $5 \%$ and $10 \%$ sodium bicarbonate in maxillary infiltrations. J Endod 2013; 39: 597-9.

24. Chow MY, Sia AT, Koay CK, Chan YW. Alkalinization of lidocaine does not hasten the onset of axillary brachial plexus block. Anesth Analg 1998; 86: 566-8.
25. Saraf SP, Saraf PA, Kamatagi K, Hugar S, Tagmond S, Patil J. A comparative evaluation of anesthetic efficacy of articaine $4 \%$ and lidocaine $2 \%$ with anterior middle superior alveolar nerve block and infraorbital nerve block: An in vivo study. J Conserv Dent 2016; 19: 527-31.

26. Kambalimath DH, Dolas RS, Kambalimath HV, Agarwal MS. Efficacy of $4 \%$ articaine and $2 \%$ lidocaine: a clinical study. J Maxillofac Oral Surg 2013; 12: 3-10. 